\title{
Entrepreneurial Diversity and Economic Growth
}

\author{
Ingrid Verheul and André van Stel
}

\begin{tabular}{|l|l|}
\hline \multicolumn{2}{|l|}{ ERIM REPORT SERIES RESEARCH IN MANAGEMENT } \\
\hline ERIM Report Series reference number & ERS-2007-070-ORG \\
\hline Publication & October 2007 \\
\hline Number of pages & 26 \\
\hline Persistent paper URL & http://hdl.handle.net/1765/10619 \\
\hline Email address corresponding author & verheul@few.eur.nl \\
\hline Address & Erasmus Research Institute of Management (ERIM) \\
& RSM Erasmus University / Erasmus School of Economics \\
& Erasmus Universiteit Rotterdam \\
& P.O.Box 1738 \\
& 3000 DR Rotterdam, The Netherlands \\
& Phone: + 31104081182 \\
& Fax: $\quad+31104089640$ \\
& Email: info@erim.eur.nl \\
& Internet: $\quad$ www.erim.eur.nl \\
\hline
\end{tabular}

Bibliographic data and classifications of all the ERIM reports are also available on the ERIM website: www.erim.eur.nl 


\section{ERASMUS RESEARCH INSTITUTE OF MANAGEMENT}

\section{REPORT SERIES}

\section{RESEARCH IN MANAGEMENT}

\begin{tabular}{|l|l|}
\hline \multicolumn{2}{|l|}{ ABSTRACT AND KEYWORDS } \\
\hline Abstract & $\begin{array}{l}\text { Most studies investigating the relationship between entrepreneurship and economic growth treat } \\
\text { entrepreneurs as a homogeneous group. This study investigates the impact of entrepreneurial } \\
\text { diversity on national economic growth. Using data for 36 countries participating in the Global } \\
\text { Entrepreneurship Monitor we investigate whether the impact on growth depends on socio- } \\
\text { demographic diversity in entrepreneurship (in terms of age, education and gender). We find that } \\
\text { in less developed countries older and higher educated entrepreneurs are particularly important } \\
\text { for stimulating economic growth, while for developed countries younger entrepreneurs are more } \\
\text { important. Accordingly, policy should aim at stimulating particular groups of entrepreneurs, rather } \\
\text { than just the number of entrepreneurs. }\end{array}$ \\
\hline Free Keywords & entrepreneurship, diversity, economic development \\
\hline Availability & $\begin{array}{l}\text { The ERIM Report Series is distributed through the following platforms: } \\
\text { Academic Repository at Erasmus University (DEAR), DEAR ERIM Series Portal } \\
\text { Social Science Research Network (SSRN), SSRN ERIM Series Webpage } \\
\text { Research Papers in Economics (REPEC), REPEC ERIM Series Webpage }\end{array}$ \\
\hline Classifications & $\begin{array}{l}\text { The electronic versions of the papers in the ERIM report Series contain bibliographic metadata } \\
\text { by the following classification systems: } \\
\text { Library of Congress Classification, (LCC) LCC Webpage } \\
\text { Journal of Economic Literature, (JEL), JEL Webpage } \\
\text { ACM Computing Classification System CCS Webpage } \\
\text { Inspec Classification scheme (ICS), ICS Webpage }\end{array}$ \\
\hline
\end{tabular}




\title{
Entrepreneurial diversity and economic growth
}

\author{
Ingrid Verheul
}

Assistant Professor, Erasmus University Rotterdam, Department of Applied Economics Centre for Advanced Small Business Economics, H12-18

P.O. Box 1738, 3000 DR Rotterdam, the Netherlands

Tel. +31 10 4081422, E-mail: verheul@few.eur.nl

EIM Business and Policy Research

P.O. Box 7001, 2701 AA Zoetermeer, the Netherlands

\author{
André van Stel \\ Researcher, EIM Business and Policy Research \\ P.O. Box 7001, 2701 AA Zoetermeer, the Netherlands \\ Tel.+31 79 3430200, E-mail: ast@eim.nl \\ Cranfield University School of Management \\ Cranfield, Bedford, MK43 OAL, United Kingdom
}

Acknowledgement: The authors are grateful to Jolanda Hessels for her support and valuable input.

Document: Verheul van Stel diversity EIM v8.doc 25-9-2007 11:48 


\title{
Entrepreneurial diversity and economic growth
}

\begin{abstract}
:
Most studies investigating the relationship between entrepreneurship and economic growth treat entrepreneurs as a homogeneous group. This study investigates the impact of entrepreneurial diversity on national economic growth. Using data for 36 countries participating in the Global Entrepreneurship Monitor we investigate whether the impact on growth depends on socio-demographic diversity in entrepreneurship (in terms of age, education and gender). We find that in less developed countries older and higher educated entrepreneurs are particularly important for stimulating economic growth, while for developed countries younger entrepreneurs are more important. Accordingly, policy should aim at stimulating particular groups of entrepreneurs, rather than just the number of entrepreneurs.
\end{abstract}

\section{Introduction}

Several studies have discussed and empirically investigated the link between entrepreneurial activity and economic performance at the level of cities, regions and nations (Iyigun and Owen, 1999; Audretsch and Keilbach, 2004; Carree et al., 2002). In these studies entrepreneurs are often treated as a homogeneous group. However, already in the 1980s Gartner (1985, p. 696) argued that: "The diversity among entrepreneurs and their ventures may be larger than the differences between entrepreneurs and non-entrepreneurs and between entrepreneurial firms and non-entrepreneurial firms". Indeed, in practice we see extensive variation between entrepreneurs, for example in terms of motivations, human capital, goals, etc. Notwithstanding the importance of the number of small firms for economic performance, this (pure) diversity within the small business population may also play a role over and above the sheer quantity effect. It should be noted however that a higher number of enterprises 'an sich' also implies higher diversity. ${ }^{1}$

The importance of diversity in entrepreneurship can be better understood in the context of an increasing diversity in demand. Indeed, market demand has become more diverse, induced by an increase in prosperity (Jackson, 1984) and reinforced by the processes of individualization and globalization. Hence, for achieving high rates of economic growth it is important that there is a diverse supply of goods and services to match this demand for variety. A greater diversity of the entrepreneurial population - in terms of characteristics of entrepreneurs and their firms - will contribute to this supply variation.

Cohen and Malerba (2001) distinguish between three important effects of diversity on technological performance within industries, including a selection effect, a breadth effect and 
a complementarity effect. Here we apply these effects within the context of national economic performance. The selection effect can be traced back to evolutionary economic thought, referring to competition between diverse firms where the best performing ones survive, leading to higher quality of products and services offered. ${ }^{2}$ According to Cohen and Malerba (2001) a higher diversity of the firm population leads to a higher expected quality per unit cost of the selected variant. The breadth effect refers to the importance of the availability of a broad range of products at the industry level for the vitality of the industry, offering opportunities for (incremental) innovations and the introduction of other (related) products in the market. The complementarity effect refers to a more complete supply of goods and services available to consumers, which can be seen as a direct welfare effect.

In the present study we try to empirically establish the relative importance of these different effects of entrepreneurial diversity. In particular, we will use measures for the size of a country's entrepreneurial population and the composition of this population (in terms of the shares of certain groups within the entrepreneurial population with specific sociodemographic characteristics), and investigate their relative impact on national economic growth. Because a greater size of the entrepreneurial population (i.e., more entrepreneurs) implies stronger competition, we will refer to the competition effect when describing the effect of the size variable on national economic performance. By and large, the competition effect corresponds with the selection effect as identified by Cohen and Malerba (2001). Because the composition variables measure the importance of specific groups of entrepreneurs within the entrepreneurial population (independent of the size of this population), we will refer to the pure diversity effect when describing the impact of these composition variables. By and large, the composition variables capture the breadth effect and the complementarity effect as proposed by Cohen and Malerba (2001).

Concerning the impact of entrepreneurial diversity, literature suggests that firm outcomes are conditional upon the type of diversity (Pelled, 1996). In this study we focus on particular groups of entrepreneurs, including women, older and higher-educated individuals. This means that entrepreneurial diversity is investigated in terms of gender, age and education. We use these socio-demographic proxies for diversity as they have been found important in determining the decision to become self-employed (Blanchflower et al., 2001; Delmar and Davidsson, 2000; Grilo and Irigoyen, 2006) and entrepreneurial performance (Parker and van Praag, 2006; Sapienza and Grimm, 1997; Cliff, 1998). Also, these groups of entrepreneurs have become more important (in terms of numbers) in recent years due to social 
developments such as the process of gender mainstreaming, the ageing society combined with a higher retirement age to support the welfare system, and the rise of the knowledgebased economy. Indeed, in the Netherlands we see an increase in start-up rates in particular for women, older people (over the age of 50 years) and higher educated individuals between 1994 and 2003 (Bruins, 2004) $)^{3}$.

To test for the effect of entrepreneurial diversity on national economic performance, we use data from the Global Entrepreneurship Monitor (GEM). Using a cross-country data sample we investigate the impact of both the size and the composition (in terms of gender, age or education) of a country's entrepreneurial population on GDP growth, while controlling for a range of relevant determinants.

The paper is structured as follows. In Section 2 we discuss the concept of diversity and how it is dealt with in different theories. We will also pay attention to the role of entrepreneurship in economic performance and the linkages between entrepreneurship and diversity. Section 3 discusses the data sample, the variables included in the study and the research model. Also, descriptive statistics are presented of the entrepreneurship variables. In Section 4 the results are presented and discussed and Section 5 concludes.

\section{Diversity, performance and entrepreneurship}

\subsection{Diversity and performance}

The concept of diversity has been studied from different perspectives. From a social perspective diversity has been discussed, for example, in terms of the presence in the population of a variety of cultures, ethnic groups, socio-economic backgrounds, opinions, religions and gender identities. ${ }^{4}$ Within a business context one often refers to the so-called 'business case for diversity'. Many research studies have explored the link between (workforce) diversity and firm performance (e.g., Richard, 2000; Kilduff et al., 2000; Simons et al., 1999). Workforce diversity often refers to gender and ethnic diversity ${ }^{5}$, but also broader perspectives on diversity are proposed such as diversity in terms of knowledge and (cognitive) capabilities relevant to the job. Indeed, Simons et al. (1999) distinguish between more and less job-related types of diversity, and their (diverging) effects on performance. Several reasons have been brought forward why it is important to stimulate work force diversity, including lower employee turnover, lower absenteeism rates, access to a broader 
pool of talent, new ideas and improved innovation, and confidence of customers (Robinson and Dechant, 1997; Salomon and Schork, 2003).

From a more aggregate economic perspective, diversity of economic actors has been identified as an important driver of economic progress at the level of cities, regions and national economies (Jacobs, 1984; Florida, 2002; Broda and Weinstein, 2006; Saviotti, 1996). Several mechanisms linking diversity and (economic) performance have been proposed. Florida (2002) argues that the influence of diversity on economic performance runs through human capital, where a high share of creative individuals in a certain city or region attracts high-tech and innovative industries. ${ }^{6}$ Cohen and Malerba (2001) distinguish between the selection, the breadth and the complementarity effect of diversity in the firm population. The selection effect runs through increased competition, induced by an increased number of (diverse) firms. Nelson and Winter (1982) argue that diversity is an important input in the selection process where the best performing firms survive ("survival of the fittest") leading to a higher quality of supplied products. The breadth effect of diversity works through available future opportunities for new and related products, where a wide range of products within an industry opens up new avenues for (incremental) innovation, thereby securing the longevity or long-term survival of the industry. The complementarity effect refers to the fact that a varied supply of products and services enables consumers to fulfil their diverse needs.

\subsection{Diversity in entrepreneurship: gender, education and age}

Given the alleged importance of diversity for economic performance, it is worthwhile to study the variation in entrepreneurship. Within the entrepreneurship literature attention has been paid to different types of diversity, for example investigating differences between female and male entrepreneurs (gender diversity). Here we focus on differences between female and male, old and young, and higher- and lower-educated individuals. We choose these specific groups of entrepreneurs since the factors age, gender and education play an important role in explaining entrepreneurship participation and entrepreneurial performance at the firm level, as will be discussed below.

\section{Participation}

With respect to participation in entrepreneurial activity it has been found that women are less likely to participate in entrepreneurship than men (Minniti et al., 2005; Reynolds et al., 2002; Blanchflower et al., 2001, Grilo and Irigoyen, 2006). In terms of age, we see that many business owners are between 25 and 45 years old (Storey, 1994; Reynolds et al., 1999) and 
that nascent entrepreneurship rates are highest for people in the age category between 25 and 34 years old (van Gelderen, 1999; Delmar and Davidsson, 2000). For (early-stage) entrepreneurship it has been found that people with a higher education level have a higher likelihood of becoming an entrepreneur (Blanchflower et al., 2001; Grilo and Irigoyen, 2006; Davidsson and Honig, 2003; Delmar and Davidsson, 2000). ${ }^{7}$ Obviously, the extent of these differences in participation rates between the different entrepreneurial groups varies across countries.

\section{Performance}

Although at the macro level female entrepreneurs have an important contribution to job creation and GDP, we see that on average women tend to perform less well than men in terms of firm size - whether measured in terms of number of employees or financial indicators, such as profits and revenues - growth, and innovation (Watson, 2002; Cliff, 1998; Rosa et al., 1996). However, when controlling for relevant factors (related to both gender and performance) performance differentials between firms run by female and male entrepreneurs diminish or disappear (Kalleberg and Leicht, 1991; Watson and Robinson, 2003; Du Rietz and Henrekson, 2000).

Generally it is assumed that education raises the skills and knowledge of an individual, thereby leading to an increase in productivity and income (van der Sluis et al., 2005). Several entrepreneurship studies have found evidence for a positive relationship between high education (of the business founder or owner) and venture performance (Gimeno et al., 1997; Bosma et al. 2004; Burke et al., 2000; Mata, 1996; Colombo et al., 2004). ${ }^{8}$ Congregado et al. (2005) find that the probability of hiring employees (i.e., employment creation) is higher for workers with university studies than for workers with lower levels of education. Parker and van Praag (2006) find that education enhances the performance of entrepreneurial ventures both directly and indirectly (through a decrease in capital constraints). ${ }^{9}$ These studies lead us to believe that entrepreneurs with a higher level of education are more successful than less educated entrepreneurs. ${ }^{10}$

Several studies indicate that the younger the business founder is, the better his or her performance (Sapienza and Grimm, 1997; van Praag, 2003). Nevertheless, according to The Economist (1999) new ventures of people within the age category of 20 to 25 years old showed a three-year survival rate of 30 percent, as compared to a 70 percent rate for people between 50 and 55 years old in the United Kingdom. Mata (1996) finds that older 
entrepreneurs start larger firms. Weber and Schaper (2003) give an overview of the different factors influencing the likelihood of success of older entrepreneurs. Success factors include experience levels, superior networks, a stronger financial situation and higher self-efficacy levels (Blackburn et al., 1998; Peña, 2002; Schutjens and Wever, 2000; Singh and DeNoble, 2003). Factors possibly negatively affecting performance of older entrepreneurs include lower energy levels, part-time involvement and the lower inclination to pursue firm growth (Snel and Bruins, 2004).

\section{Other characteristics}

Other differences have been found between the different groups of entrepreneurs. Indeed, the different entrepreneurial groups are characterized by different personal and firm profiles. Several studies find evidence for gender differences in entrepreneurship, where female entrepreneurs start and run smaller firms; invest lower amounts of capital (Boden and Nucci, 2000; Carter and Rosa, 1998; Verheul and Thurik, 2001); are more likely to start and run a service firm (OECD, 1998); are more likely to focus upon quality than quantity of output (Chaganti and Parasuraman, 1996; Rosa et al., 1996); tend to be more risk averse (Watson and Robinson, 2003; Wagner, 2004); want to be in control of the business (Mukthar, 2002; Cliff, 1998); and invest less time in the business (Verheul et al., 2006a; Watson, 2002). Entrepreneurs with different education levels have been found to differ with respect to the financial capital structure in their firms, where high educated entrepreneurs invest larger sums of money in their businesses (Bates, 1990; Astebro and Bernhardt, 2005). In addition, Colombo and Delmastro (2001) find that new technology-based firms tend to have business founders and owners with relatively high education levels. With respect to entrepreneurs of different age, it has been suggested that older entrepreneurs may be pushed into entrepreneurship because of diminishing opportunities in wage-employment or insufficient retirement systems and that they are more likely than younger individuals to start in financial and business services (Weber and Schaper, 2003; Snel and Bruins, 2004).

In sum, literature shows that, when comparing female with male; young with old; and higheducated with low-educated entrepreneurs, there are differences in terms of participation, performance and (firm) characteristics. These differences may be important when explaining performance at the macro level. In the subsequent sections we will empirically explore the influence of the various socio-economic entrepreneurial groups on macro-economic performance. 


\section{Data and research method}

In the present study we investigate whether - next to the size of a country's entrepreneurial population - also the composition of the entrepreneurial population influences national economic growth. The size of a country's entrepreneurship population is measured by the Total early-stage Entrepreneurial Activity (TEA) index, defined as the percentage of the adult population that is either actively involved in starting a new venture or is the owner/manager of a business that is less than 42 months old. The TEA index is taken from the Global Entrepreneurship Monitor data base. The composition of the entrepreneurial population is measured in terms of three aspects of diversity: age, education and gender. Our empirical analysis builds on van Stel et al. (2005). They investigate whether TEA influences GDP growth for a sample of 36 countries. The authors find that the TEA index indeed affects economic growth, but that the influence depends on the level of economic development. In particular, the contribution of entrepreneurial activity to economic growth is found to be stronger for high than for less developed countries. The authors argue that this may be explained by the lower human capital levels of entrepreneurs in less developed countries.

In this study we perform a similar regression analysis but, in addition to the TEA index, we also include selected diversity indices and investigate whether these indices provide additional explanatory power to the model. We use a sample of 36 countries participating in the Global Entrepreneurship Monitor (GEM) in 2002. Data on seven basic variables are used in our model: TEA; age composition of entrepreneurship; education composition of entrepreneurship; gender composition of entrepreneurship; GDP growth; per capita income; and the growth competitiveness index (GCI). The sources and definitions of these variables are described below.

\section{Total early-stage Entrepreneurial Activity (TEA)}

TEA is defined as the percentage of adult population that is either actively involved in starting a new venture or is the owner/manager of a business that is less than 42 months old. Data on total entrepreneurial activity are taken from the GEM Adult Population Survey for 2002.

\section{Age composition of entrepreneurship}

For this category we construct three age category variables including the share in the total number of entrepreneurs that is relatively young (18-24 years), middle-aged (25-44), or relatively old (45-64). 


\section{Education composition of entrepreneurship}

We construct three education category variables: the share in the total number of entrepreneurs that has a low level of education (no, primary or some secondary education), a middle level of education (secondary education), or a high level of education (university level or post-graduate education). ${ }^{11}$

\section{Gender composition of entrepreneurship}

The gender composition of entrepreneurship is measured using the share of female entrepreneurs in a country's total number of entrepreneurs.

\section{Growth of GDP ( $\triangle$ GDP)}

Real GDP growth rates are taken from the IMF World Economic Outlook database of the International Monetary Fund, version September 2005.

6. Per capita income (GNIC)

Gross national income per capita 2001 is expressed in (thousands of) purchasing power parities per US\$, and these data are taken from the 2002 World Development Indicators data base of the World Bank.

\section{Growth Competitiveness Index (GCI)}

Data on the Growth Competitiveness Index 2001 are taken from The Global Competitiveness Report 2001-2002 (page 32). The GCI is constituted of the following three main factors assessing a country's potential for economic growth: the quality of the macro-economic environment, the state of the public institutions, and the level of technology. For further details about this index we refer to McArthur and Sachs (2002).

We investigate whether - next to per capita income, technology, public institutions, and the macro-economic environment (as captured by the GCI) - entrepreneurship can be considered a determinant of economic growth. As both entrepreneurship and the factors underlying the GCI are assumed to be structural characteristics of an economy, we aim to explain growth in the medium term rather than in the short term. Therefore we choose average annual growth over a period of four years (2002-2005) as the dependent variable in this study. Following van Stel et al. (2005) we use (the log of) the initial income level of countries to correct for catch-up effects. In contrast to van Stel et al. (2005), we do not use lagged GDP growth since we are able to measure TEA in a year (2002) preceding the period over which we measure economic growth. Nevertheless, we will include the lagged growth variable in robustness tests. 
Following van Stel et al. (2005) we allow for different effects for richer and poorer countries. ${ }^{12}$ Indeed, TEA rates may include different types of entrepreneurs in countries with different levels of development, suggesting different impacts on growth in these countries. We test for this divergence in effects by defining separate TEA variables for rich and poor countries.

Our model is represented by Equations (1) to (3). These equations are estimated separately using OLS regressions. The hypothesis of a larger positive effect for rich countries corresponds to a situation where $\mathrm{b}>\mathrm{c}$. In each of the three equations a different aspect of entrepreneurial diversity is investigated. In Equation (1) the shares of relatively young and old entrepreneurs are included in the analysis, with the share of entrepreneurs in the middle age class as a reference group to avoid multicollinearity. Similarly, in Equation (2) the shares of low and high educated entrepreneurs are included in the regression (with the group of middle-educated entrepreneurs as the reference group). Finally, in Equation (3) we use the share of female entrepreneurs (with male entrepreneurs as the reference group). We will also run variants of this model where the impact of these three different aspects of diversity is allowed to differ between rich and poor countries.

$$
\begin{aligned}
& \Delta G D P_{\mathrm{it}}=a+b T E A_{\mathrm{i}, \mathrm{t}-1}^{\text {rich }}+c T E A_{\mathrm{i}, \mathrm{t}-1}^{\text {poor }}+d \log \left(G N I C_{\mathrm{i}, \mathrm{t}-1}\right)+e G C I_{\mathrm{i}, \mathrm{t}-1} \\
& +f_{1} \text { share young } E+f_{2} \text { share old } E+\varepsilon_{\mathrm{it}} \\
& \Delta G D P_{\mathrm{it}}=a+b T E A_{\mathrm{i}, \mathrm{t}-1}^{\text {rich }}+c T E A_{\mathrm{i}, \mathrm{t}-1}^{\text {poor }}+d \log \left(G N I C_{\mathrm{i}, \mathrm{t}-1}\right)+e G C I_{\mathrm{i}, \mathrm{t}-1} \\
& +f_{1} \text { share low educ } E+f_{2} \text { share high educ } E+\varepsilon_{i t} \\
& \Delta G D P_{\mathrm{it}}=a+b T E A_{\mathrm{i}, \mathrm{t}-1}^{r i c h}+c T E A_{\mathrm{i}, \mathrm{t}-1}^{\text {poor }}+d \log \left(G N I C_{\mathrm{i}, \mathrm{t}-1}\right)+e G C I_{\mathrm{i}, \mathrm{t}-1} \\
& +f_{1} \text { share female } E+\varepsilon_{\text {it }}
\end{aligned}
$$

Table 1 provides descriptive statistics of the entrepreneurship indicators. The average TEA index is 8.1 with TEA rates varying between 1.8 for Japan and 18.9 for Thailand. Japan also has extreme low scores in terms of the percentage of young entrepreneurs $(0.0)$ and the share of female entrepreneurs (17.6\%). With respect to age we see that on average the highest share of entrepreneurs $(60.6 \%)$ can be found in the mid-age group (i.e. 25-44), which corresponds with the literature (Storey, 1994; Reynolds et al., 1999). Furthermore, we see that the three education groups - on average - are fairly evenly distributed. ${ }^{13}$ The maximum share of low- 
educated entrepreneurs (74.7\%) can be found in India whereas Denmark has the highest share of high-educated entrepreneurs $(83.3 \%)$. For female entrepreneurship we see that the average percentage in 2002 is $34 \%$ with a minimum of $17.6 \%$ for Japan and a maximum of $49.5 \%$ for Thailand. From the standard deviations we can see that there is quite some variation between the countries with respect to the entrepreneurial diversity variables. In the next section we investigate whether these variations influence national economic growth.

\section{--- TABLE 1 ABOUT HERE ---}

\section{Results}

The results of our empirical analyses are presented in Tables 2 through 5. In Table 2 the regression results of the impact of the general TEA index on economic growth are presented. Tables 3, 4 and 5 show the results including the entrepreneurial composition measures as additional determinants.

--- TABLE 2 ABOUT HERE ---

--- TABLE 3 ABOUT HERE ---

--- TABLE 4 ABOUT HERE ---

\section{--- TABLE 5 ABOUT HERE ---}

The results in Table 2 confirm earlier findings of van Stel et al. (2005) that it is important to distinguish between different groups of countries. Whereas for rich countries the impact of entrepreneurial activity is significantly positive, the impact for poor countries is effectively zero. $^{14}$

Table 3 focuses on entrepreneurial diversity in terms of age. As compared to Table 2 we have included the share of young entrepreneurs (18-24 years) and the share of older entrepreneurs (45-64). Coefficients for these two variables should be interpreted relative to the reference group (25-44 years). From the results of models 1 and 2 we see that the age variables do not 
add to the explanation of economic growth (t-values are below unity). In model 3 we test whether, like TEA, the impact of the two age groups differs for rich and poor countries. This appears to be the case. ${ }^{15}$ Model 3 reveals that in richer countries the younger entrepreneurs (18-24) have a higher contribution to economic growth as compared to mid-age and older entrepreneurs, while in poorer countries the older entrepreneurs (45-64) have a higher contribution to economic growth. It appears that in the richer developed countries, with a well-developed infrastructure supporting entrepreneurship, it is beneficial to have many young entrepreneurs challenging the established routines with new ideas, thereby introducing more dynamics into the system. ${ }^{16}$ In less developed countries, on the other hand, entrepreneurship is a less well-known and stimulated phenomenon and it may be expected that people have less experience with starting up and running a business. In many cases people start firms to escape a situation of low-pay wage jobs or unemployment, without the knowledge and skills required to successfully run a business. In such a setting it is important to have more experienced (successful) entrepreneurs around who not only have an important contribution themselves, but are also able and willing to engage in mentoring of new entrepreneurs.

Table 4 focuses on entrepreneurial diversity in terms of education. Compared to Table 2 we have included the share of low-educated and that of high-educated entrepreneurs in the analysis. Coefficients for these two variables should be interpreted relative to the reference group (mid-level education). For models 1 and 2 we see that the education variables do not have a significant impact. For model 3 we find a relatively strong effect for the share of high educated entrepreneurs in less developed countries (significant at 5\% level). This is in line with van Stel, Carree and Thurik (2005) who argue that in developing countries it is the quality of entrepreneurial supply (measured by education levels of entrepreneurs) rather than the quantity of entrepreneurial supply (as measured by TEA) that contributes to economic growth. Indeed, developing countries tend to be characterized by a relatively high share of socalled necessity entrepreneurs (vis-à-vis opportunity entrepreneurs). ${ }^{17}$ It has been argued that necessity entrepreneurs have a lower contribution to economic growth than opportunity entrepreneurs (Reynolds et al., 2002). ${ }^{18}$

Finally, Table 5 focuses on gender diversity. Although not statistically significant we find a negative sign for the share of female entrepreneurs across the three models. The negative impact seems to be more pronounced for rich countries. This raises questions about the relevance of policies designed to increase levels of female entrepreneurship. It is important 
for governments to clearly formulate and understand the targets to be pursued by policy. For example, do governments aim to stimulate the number of female entrepreneurs or the female share in entrepreneurship (i.e., the gender diversity of entrepreneurship)? This distinction is relevant since Verheul et al. (2006b) show that there may be different mechanisms involved in achieving these targets. The results in Table 5 suggest that, if the underlying goal of economic policy is to enhance economic growth, generic entrepreneurship policy (i.e., stimulating entrepreneurial activity in general) may be preferred over policies specifically designed to stimulate female entrepreneurship. Although in richer countries female entrepreneurs - like male entrepreneurs - contribute positively to economic growth (as can be seen by the positive impact of the TEA rate), there is no evidence that a higher share of women within the entrepreneurship population enhances growth beyond this 'general' impact of the number of female entrepreneurs. From this perspective it may be argued that policies specifically aimed at creating advantages for women (e.g., 'positive discrimination') are not favorable for achieving economic growth.

Our regression results should be interpreted with some care as the analysis is based on a limited number of observations (36 countries). However, despite the small number of observations, the results appear to be robust. First, the coefficients for the control variables are intuitive in all model specifications. In particular, we find a negative sign for the catching up variable $(\log (\mathrm{GNIC}))$ and a consistently positive effect for the Growth Competitiveness Index across all specifications. Second, although we measure our independent variables at a time preceding the period of the dependent variable - on the basis of which we decided not to include lagged GDP growth in our models - we did run model variants including lagged GDP growth (period 1998-2001) as a robustness test. The main results, as described above, remained unchanged although in some cases significance levels became somewhat lower. ${ }^{19}$

\section{Discussion and conclusion}

Research suggests that there is substantial diversity among entrepreneurs and their ventures (Gartner, 1985). These differences with respect to - for example - skills, knowledge, personality, motivation and goals explain (at least in part) differences in venture performance (Baum et al., 2001). However, at the more aggregate (macro) level there has been less attention for the relationship between diversity and economic performance. The present study investigates the extent to which entrepreneurial diversity has an effect on national economic growth over and above the sheer number of entrepreneurs. 
We distinguish between a competition effect of diversity (where economic growth results from more fierce competition among a higher number of firms), measured by the size of the entrepreneurial population (i.e., the TEA rate), and a 'pure' diversity effect (where entrepreneurial activity of different socio-demographic groups may have a different impact on macro-economic performance), measured in terms of the composition of the entrepreneurial population (in terms of gender, age or education).

The empirical analysis shows that the contribution of entrepreneurship in general depends upon the level of economic development. In conformity with the results of van Stel et al. (2005) we find that the size of the entrepreneurship population has a positive impact on economic growth in the rich, developed countries but no impact in the less developed countries. Hence, we find support for the existence of a competition effect in the rich countries, i.e., a higher number of entrepreneurs appears to serve as input for a selection process where the best performing firms survive, ultimately leading to higher levels of economic growth. In less developed countries an increase in the number of entrepreneurs is not associated with higher growth, i.e., there is no evidence of a competition effect in these countries. Instead of intensifying the competition process through the wish to excel and challenge incumbent firms with new products or new techniques of production (i.e., knowledge-intensive entrepreneurial activity), the many 'shopkeeper' and necessity type entrepreneurs in these countries may simply want to earn a living through starting up and running a business.

With respect to the 'pure' diversity effect of entrepreneurship there are several interesting results. First, we find that the age composition of the entrepreneurial population matters in explaining economic growth. More specifically, the effect of the share of younger or older entrepreneurs on economic growth depends upon the level of economic development. In higher developed countries younger entrepreneurs appear to have a particularly important contribution to economic growth, whereas in less developed countries, older entrepreneurs are more important. This suggests that richer countries benefit from more dynamism and new ideas from young entrepreneurs, contributing to a process of creative destruction, whereas less developed countries benefit from more experienced entrepreneurs to create a knowledge infrastructure supporting successful new venture creation.

Second, we find that in less developed countries particularly high-educated entrepreneurs are important for achieving economic growth. However, these countries tend to be characterized by a relatively low share of high-educated entrepreneurs. In our sample the average share of 
high-educated entrepreneurs is significantly lower for the poor countries $(24.6 \%)$ as compared to the rich countries $(43.9 \%)$. This may be due to the fact that higher-educated people in developing countries often leave their country to find a job in more developed countries where they may receive higher salary or facilities. From a policy perspective, it is important that less developed countries prevent the negative consequences of this 'brain drain' and the relatively low level of education characterizing its population by creating a more attractive work environment for higher-educated people; investing in education of the labor force and in particular (potential) self-employed people; and attracting higher educated entrepreneurs to help stimulate the economy.

Finally, we did not find evidence for a differential impact on economic growth of female and male entrepreneurs. As discussed earlier, our results suggest that stimulating female entrepreneurs is important (we find that - in rich countries - entrepreneurship in general has a positive influence on growth), but not at the expense of male entrepreneurs by way of 'positive discrimination' measures.

The findings in our paper have important policy implications. In particular, one may argue that a significant effect of the size of a country's entrepreneurial population calls for creating generic entrepreneurship policies (that are applicable to all types of entrepreneurs), whereas the significant effects of groups of entrepreneurs calls for programs targeting these specific groups. Our results suggest that in high developed countries generic entrepreneurship policy is important (since the impact of the TEA rate is positive), with a special focus on stimulating entrepreneurship among young people (the impact of the share of young entrepreneurs is also positive). For less developed countries our results indicate that it is important to stimulate entrepreneurship among higher-educated individuals and people within the age category of 45 to 64 years old. Governments in these countries should stimulate the accessibility of the know-how of these experienced entrepreneurs to the wider public. In general, generic entrepreneurship policies seem to be less efficient in less developed countries since they are likely to stimulate and attract necessity entrepreneurs.

There is a methodological issue that we did not discuss up until this point. It may be argued that - strictly speaking - it is not really diversity that we measure in this paper. Diversity is often associated with measures of the spread or variance of a certain phenomenon. For instance, in this study one may argue that entrepreneurial diversity in terms of education is maximal if all three education levels represent one third of the total number of entrepreneurs. On the other hand, one may argue that diversity is low if this distribution would be skewed. 
These different situations could be measured with Herfindahl type measures. A disadvantage of such measures is that it is not possible to distinguish between the relative importance of the different entrepreneurial groups. For example, a positive impact of the variance over the different groups implies that economic growth can be enhanced by creating a skewed distribution over the different groups. However this does not indicate in which direction the distribution should be skewed, i.e. which groups should be stimulated or discouraged (e.g., entrepreneurs with low, middle or high education). By way of including the shares of all different groups in our model we are able to distinguish between the relative importance of different entrepreneurial groups.

In addition to gender, age and education, future research may focus on other types of entrepreneurs, such as ethnic, portfolio or habitual entrepreneurs. Our data base prevented us from including other types of entrepreneurial diversity in the analysis. Moreover, as it can be expected that there is interaction between socio-demographic characteristics, it will be interesting to find out whether there are interaction effects, e.g., whether young high-educated people are more important for achieving growth than old high-educated self-employment individuals.

\section{References}

Astebro, T.B. and I. Bernhardt, 2005, The winner's curse of human capital, Small Business Economics 24 (1), 63-78.

Audretsch, D.B. and M. Keilbach, 2004, Entrepreneurship capital and economic performance, Regional Studies 38 (8), 949-959.

Bates, T., 1990, Entrepreneur human capital inputs and small business longevity, The Review of Economics and Statistics 72 (4), 551-559.

Blackburn, R., Mackintosh, L. and J. North, 1998, Entrepreneurship in the Third Age, Surrey, UK: Kingston University Entrepreneurship Centre.

Blanchflower, D.G., Oswald, A. and A. Stutzer, 2001, Latent entrepreneurship across nations, European Economic Review 45, 680-691.

Boden Jr., R.J. and A.R. Nucci, 2000, On the survival prospects of men's and women's new business ventures, Journal of Business Venturing 15 (4), 347-362. 
Bosma, N., C.M. van Praag, A.R. Thurik and G. de Wit, 2004, The value of human and social capital investments for the business performance of start-ups, Small Business Economics $23,227-236$.

Broda, C. and Weinstein, 2006, Globalization and the gains from variety, Quarterly Journal of Economics 121 (2), 541-585.

Bruins, A., 2004, Starten in de recessie; startende ondernemers in 2003 [Starting up in a recession; starting etrepreneurs in 2003], Report A200403, Zoetermeer: EIM Business and Policy Research.

Burke, A.E., FitzRoy, F.R. and M.A. Nolan, 2000, When less is more: distinguishing between entrepreneurial choice and performance, Oxford Bulletin of Economics and Statistics 62 (5), 565-587.

Carree, M.A., Stel, A.J. van, Thurik, A.R. and A.R.M. Wennekers, 2002, Economic development and business ownership: an analysis using data of 23 OECD countries in the period 1976-1996, Small Business Economics 19 (3), 271-290.

Carter, S. and P. Rosa, 1998, The financing of male- and female-owned businesses, Entrepreneurship and Regional Development 10, 225-241.

Chaganti, R. and S. Parasuraman, 1996, A study of the impacts of gender on business performance and management patterns in small businesses, Entrepreneurship: Theory and Practice, Winter 1996, 73-75.

Cliff, J.E., 1998, Does one size fit all? Exploring the relationship between attitudes towards growth, gender, and business size, Journal of Business Venturing 13, 523-542.

Cohen, W.M. and S. Klepper, 1992, The trade-off between firm size and diversity in the pursuit of technological progress, Small Business Economics 4 (1), 1-14.

Cohen, W.M. and F. Malerba, 2001, Is the tendency to variation a chief cause of progress?, Industrial and Corporate Change 10 (3), 587-608.

Colombo, M.G., and M. Delmastro, 2001, Technology-based entrepreneurs: Does Internet make a difference?, Small Business Economics 16, 177-190.

Colombo, M.G., Delmastro, M. and L. Grilli, 2004, Entrepreneurs' human capital and the start-up size of new technology-based firms, International Journal of Industrial Organization 22 (8-9), 1183-1211.

Congregado, E., Golpe, A. and J.M. Millán, 2005, Determinantes de la oferta de empresarios, in: García, J. and J. Pérez (eds.), Cuestiones Clave de la Economía Española, Perspectivas actuales 2004, Ed. Comares, 165-187.

Cressy, R., 1996, Are business startups debt-rationed?, Economic Journal 106, 1253-1270. 
Davidsson, P. and B. Honig, 2003, The role of social and human capital among nascent entrepreneurs, Journal of Business Venturing 18 (3), 301-331.

Delmar, F. and P. Davidsson, 2000, Where do they come from? Prevalence and characteristics of nascent entrepreneurs, Entrepreneurship and Regional Development 12 (1), $1-23$.

Du Rietz, A. and M. Henrekson, 2000, Testing the female underperformance hypothesis, Small Business Economics, 1-10.

Evans, D.S. and L.S. Leighton, 1989, Some empirical aspects of entrepreneurship, American Economic Review 79 (3), 519-535.

Florida, R., 2002, The Rise of the Creative Class and How It is Transforming Work, Leisure, Community and Everyday Life, New York: Basic Books.

Gartner, W.B., 1985, A conceptual framework for describing the phenomenon of new venture creation, Academy of Management Review 10 (4), 696-706.

Gelderen, M.W. van, 1999, Ontluikend ondernemerschap [Nascent entrepreneurship], Strategic Study B9807, Zoetermeer: EIM Business and Policy Research.

Gimeno, J., Folta, T.B., Cooper, A.C. and C.Y. Woo, 1997, Survival of the fittest? Entrepreneurial human capital and the persistence of underperforming firms, Administrative Science Quarterly 42 (4), 750-783.

Grilo, I. and J.M. Irigoyen, 2006, Entrepreneurship in the EU: to wish and not to be, Small Business Economics 26 (4), 305-318.

Grilo, I. and A.R. Thurik, 2005, Latent and actual entrepreneurship in Europe and the US: some recent developments, International Entrepreneurship and Management Journal 1 (4), 441-459.

Hannan, M.T. and J. Freeman, 1989, Organizational Ecology, Cambridge MA: Harvard University Press.

Iyigun, M.F. and A.L. Owen, 1999, Entrepreneurs, professionals and growth, Journal of Economic Growth 4 (2), 213-232.

Jackson, L.F., 1984, Hierarchic demand and the Engle curve for variety, Review of Economics and Statistics 66, 8-15.

Jacobs, J., 1984, Cities and the Wealth of Nations; Principles of Economic Life, New York: Random House.

Kalleberg, A.L. and K.T. Leicht, 1991, Gender and organizational performance: determinants of small business survival and success, Academy of Management Journal 34 (1), 136-161. 
Kilduff, M., Angelmar, R. and A. Mehra, 2000, Top management-team diversity and firm performance: examining the role of cognitions, Organization Science 11 (1), 21-34.

Mata, J., 1996, Market, entrepreneurs and the size of new firms, Economic Letters 52 (1), 8994.

McArthur, J.W., and J.D. Sachs, 2002, The Growth Competitiveness Index: Measuring technological advancement and the stages of development, in: M.E. Porter, J.D. Sachs, P.K. Cornelius, J.W. McArthur, K. Schwab (eds.), The Global Competitiveness Report 2001-2002, New York: Oxford University Press, 28-51.

Minniti, M., Arenius, P. and N. Langowitz, 2005, Global Entrepreneurship Monitor: 2004 Report on Women and Entrepreneurship, Centre for Women's Leadership at Babson College / London Business School.

Minniti, M., Bygrave, W.D. and E. Autio, 2006, Global Entrepreneurship Monitor, 2005 Executive Report, Babson College and London Business School.

Mukhtar, S-M., 2002, Differences in male and female management characteristics: a study of owner-manager businesses, Small Business Economics 18, 289-311.

Nelson, R.R. and S.G. Winter, 1982, An Evolutionary Theory of Economic Change, Cambridge MA: Harvard University Press.

OECD, 1998, Women Entrepreneurs in Small and Medium Enterprises, OECD Conference Paris 1997, Paris: OECD.

Parker, S.C. and C.M. van Praag, 2006, Schooling, capital constraints, and entrepreneurial performance: the endogenous triangle, Journal of Business and Economic Statistics 24 (4), 416-431.

Pelled, L.H., 1996, Demographic diversity, conflict, and work group outcomes: an intervening process theory, Organization Science 7 (6), 615-631.

Peña, I., 2002, Intellectual capital and business start-up success, Journal of Intellectual Capital 3 (2), 180-198.

Praag, C.M. van, 2003, Business survival and success of young small business owners, Small Business Economics 21 (1), 1-17.

Reynolds, P.D., 1997, Who starts new firms? Preliminary explorations of firms-in-generation, Small Business Economics 9, 449-462.

Reynolds, P.D., Hay, M. and S.M. Camp, 1999, Global Entrepreneurship Monitor: 1999 Executive Report, Babson College; Kauffman Center for Entrepreneurial Leadership; London Business School. 
Reynolds, P.D., Bygrave, W.D., Autio, E., Cox, L.W. and M. Hay, 2002, Global Entrepreneurship Monitor: Executive Report, Babson College / London Business School / Kauffman Foundation.

Richard, O.C., 2000, Racial diversity, business strategy, and firm performance: a resourcebased view, Academy of Management Journal 43 (2), 164-177.

Robinson, G. and K. Dechant, 1997, Building a business case for diversity, The Academy of Management Executive 11 (3), 21-31.

Rosa, P., Carter, S. and D. Hamilton, 1996, Gender as a determinant of small business performance: Insights from a British study, Small Business Economics 8, 463-478.

Salomon, M.F. and J.M. Schork, 2003, Turn diversity to your advantage, Technology Management, July-August 2003, 37-44.

Sapienza, H.J. and C.M. Grimm, 1997, Founder characteristics, start-up process, and strategy/structure variables as predictors of shortline railroad performance, Entrepreneurship Theory and Practice 22 (1), 5-24.

Saviotti, P.P., 1996, Technological Evolution, Variety and the Economy, Cheltenham, UK: Edward Elgar.

Schutjens, V. and E. Wever, 2000, Determinants of new firm success, Papers in Regional Science 79 (2), 135-153.

Simons, T., Pelled, L.H. and K.A. Smith, 1999, Making use of difference: diversity, debate, and decision comprehensiveness in top management teams, Academy of Management Journal 42 (6), 662-673.

Singh, G. and A. DeNoble, 2003, Early retirees as the next generation of entrepreneurs, Entrepreneurship Theory and Practice 28 (3), 207-226.

Sluis, J. van der, Van Praag, C.M. and W. Vijverberg, 2005, Entrepreneurship selection and performance: a meta-analysis of the impact of education in developing economies, The World Bank Economic Review 19 (2), 225-261.

Snel, D. and A. Bruins, 2004, Oudere versus jongere starters (Old versus young start-up entrepreneurs), EIM Report A200410, Zoetermeer: EIM Business and Policy Research.

Stel, A.J. van, M.A. Carree and A.R. Thurik, 2005, The effect of entrepreneurial activity on national economic growth, Small Business Economics 24: 311-321.

Storey, D.J., 1994, Understanding the Small Business Sector, London/New York: Routledge.

The Economist, 1999, Face value: the pygmy problem, vol. 353, nr. 8144, 68-70.

Uhlaner, L.M. and A.R. Thurik, 2007, Post-materialism influencing total entrepreneurial activity across nations, Journal of Evolutionary Economics 17 (2), forthcoming. 
Verheul, I. and A.R. Thurik, 2001, Start-up capital: does gender matter?, Small Business Economics 16 (4), 329-345.

Verheul, I., Carree, M.A. and A.R. Thurik, 2006a, Allocation and productivity of time in new ventures of female and male entrepreneurs, Max Planck Discussion Paper on Entrepreneurship, Growth and Public Policy \#0106, Jena: Max Planck Institute of Economics.

Verheul, I., Stel, A.J. van, and A.R. Thurik, 2006b, Explaining female and male entrepreneurship at the country level, Entrepreneurship and Regional Development 18, 151-183.

Wagner, J., 2004, What a difference a Y makes: female and male nascent entrepreneurs in Germany, IZA Discussion Paper no. 1134, Bonn: Institute for the Study of Labor.

Watson, J., 2002, Comparing the performance of male- and female-controlled businesses: relating outputs to inputs, Entrepreneurship Theory and Practice 26 (3), 91-100.

Watson, J. and S. Robinson, 2003, Adjusting for risk in comparing the performances of maleand female-controlled SMEs, Journal of Business Venturing 18, 773-788.

Weber, P. and M. Schaper, 2003, Understanding the grey entrepreneur: a review of the literature, paper presented at SEAANZ, $16^{\text {th }}$ Annual Conference of Small Enterprise Association of Australia and New Zealand, Ballarat, 28 September-1 October 2003. 


\section{Tables}

Table 1: Descriptive statistics entrepreneurship variables

\begin{tabular}{|l|c|c|c|c|c|c|}
\hline & mean & $\begin{array}{c}\text { standard } \\
\text { dev. }\end{array}$ & minimum & maximum & $\begin{array}{c}\text { observations } \\
\text { countries) }\end{array}$ \\
\hline \multicolumn{7}{|c|}{ Size of entrepreneurship population } \\
\hline TEA (\% of adult population) & 8.1 & 4.6 & 1.8 & 18.9 & 36 \\
\hline \multicolumn{7}{|c|}{ Age composition of entrepreneurship } \\
\hline Share young entrepreneurs (\%) & 12.9 & 7.1 & 0.0 & 34.1 & 36 \\
\hline Share mid-age entrepreneurs (\%) & 60.6 & 7.8 & 37.2 & 74.3 & 36 \\
\hline Share old entrepreneurs (\%) & 26.4 & 8.4 & 15.9 & 62.8 & 36 \\
\hline \multicolumn{7}{|c|}{ Education composition entrepreneurship } \\
\hline Share low-educated entrepreneurs (\%) & 22.4 & 21.7 & 0.0 & 74.7 & 33 \\
\hline Share middle-educated entrepreneurs (\%) & 38.9 & 16.9 & 7.1 & 76.6 & 33 \\
\hline Share high-educated entrepreneurs (\%) & 38.6 & 17.6 & 8.5 & 83.3 & 33 \\
\hline
\end{tabular}

Table 2: Explaining economic growth from TEA rate $(\mathrm{N}=36)$

\begin{tabular}{|l|c|c|}
\hline & Model 1 & Model 2 \\
\hline Constant & $25.9 * *$ & $(3.9)$ \\
\hline TEA & $(3.9)$ & \\
& $0.014 * 2$ & \\
\hline TEA_rich countries & $(0.2)$ & $0.11^{* *}$ \\
& & $(2.0)$ \\
\hline TEA_poor countries & & -0.083 \\
& & $(1.0)$ \\
\hline log (GNIC) & & $-4.1 * *$ \\
& $-3.0 * *$ & $(3.6)$ \\
\hline GCI & $(3.3)$ & 1.1 \\
& 1.3 & $(1.3)$ \\
\hline $\mathrm{R}^{2}$ & $(1.5)$ & 0.584 \\
\hline adjusted ${ }^{2}$ & 0.518 & 0.530 \\
\hline Log-likelihood & 0.473 & -56.7 \\
\hline
\end{tabular}

Absolute heteroskedasticity-consistent $t$-values are between brackets. Dependent variable is average annual growth of GDP for the period 2002-2005. TEA is Total Entrepreneurial Activity rate (Global Entrepreneurship Monitor); GCI is Growth Competitiveness Index 2001 (Growth Competitiveness Report); GNIC is per capita income of 2001. * Significant at a 0.10 level; ** Significant at a 0.05 level. 
Table 3: Explaining growth from TEA and age composition of entrepreneurship $(\mathrm{N}=36)$

\begin{tabular}{|c|c|c|c|}
\hline & Model 1 & Model 2 & Model 3 \\
\hline Constant & $\begin{array}{l}25.0 * * \\
(3.4)\end{array}$ & $\begin{array}{l}36.5 * * \\
(3.5)\end{array}$ & $\begin{array}{l}37.8 * * \\
(3.7)\end{array}$ \\
\hline TEA & $\begin{array}{c}0.006 \\
(0.1) \\
\end{array}$ & & \\
\hline TEA_rich & & $\begin{array}{l}0.11^{*} \\
(1.8)\end{array}$ & $\begin{array}{l}0.14^{* *} \\
(2.2)\end{array}$ \\
\hline TEA_poor & & $\begin{array}{l}-0.11 \\
(1.1) \\
\end{array}$ & $\begin{array}{c}-0.072 \\
(0.8)\end{array}$ \\
\hline Share young & $\begin{array}{c}0.022 \\
(0.5) \\
\end{array}$ & $\begin{array}{c}0.043 \\
(0.9) \\
\end{array}$ & \\
\hline Share old & $\begin{array}{c}0.009 \\
(0.3)\end{array}$ & $\begin{array}{c}0.015 \\
(0.7)\end{array}$ & \\
\hline Share young, rich & & & $\begin{array}{l}0.098 * \\
(1.9)\end{array}$ \\
\hline Share old, rich & & & $\begin{array}{c}0.023 \\
(0.9) \\
\end{array}$ \\
\hline Share young, poor & & & $\begin{array}{c}-0.039 \\
(0.6)\end{array}$ \\
\hline Share old, poor & & & $\begin{array}{l}0.10^{* *} \\
(2.1)\end{array}$ \\
\hline $\log (\mathrm{GNIC})$ & $\begin{array}{l}-3.0 * * \\
(3.0)\end{array}$ & $\begin{array}{l}-4.2 * * \\
(3.2) \\
\end{array}$ & $\begin{array}{l}-4.4 * * \\
(3.5) \\
\end{array}$ \\
\hline GCI & $\begin{array}{c}1.4 \\
(1.5) \\
\end{array}$ & $\begin{array}{c}1.2 \\
(1.4) \\
\end{array}$ & $\begin{array}{c}1.2 \\
(1.5) \\
\end{array}$ \\
\hline $\mathrm{R}^{2}$ & 0.522 & 0.598 & 0.662 \\
\hline adjusted $\mathrm{R}^{2}$ & 0.443 & 0.515 & 0.561 \\
\hline Log-likelihood & -59.2 & -56.1 & -53.0 \\
\hline
\end{tabular}

Notes are similar to those reported in Table 2 . 
Table 4: Explaining growth from TEA and education composition of entrepreneurship $(\mathrm{N}=33)$

\begin{tabular}{|c|c|c|c|}
\hline & Model 1 & Model 2 & Model 3 \\
\hline Constant & $\begin{array}{l}26.7 * * \\
(3.4)\end{array}$ & $\begin{array}{l}37.4 * * \\
(3.7)\end{array}$ & $\begin{array}{l}37.2 * * \\
(4.5)\end{array}$ \\
\hline TEA & $\begin{array}{c}0.014 \\
(0.2)\end{array}$ & & \\
\hline TEA rich & & $\begin{array}{l}0.12 * \\
(1.7)\end{array}$ & $\begin{array}{l}0.17^{* *} \\
(2.9)\end{array}$ \\
\hline TEA poor & & $\begin{array}{c}-0.093 \\
(1.1)\end{array}$ & $\begin{array}{l}-0.23 \\
(1.4)\end{array}$ \\
\hline Share low educated & $\begin{array}{l}0.012 \\
(0.6) \\
\end{array}$ & $\begin{array}{c}0.020 \\
(0.9) \\
\end{array}$ & \\
\hline Share high educated & $\begin{array}{l}0.020 \\
(0.9)\end{array}$ & $\begin{array}{l}0.026 \\
(1.2)\end{array}$ & \\
\hline Share low educated, rich & & & $\begin{array}{l}0.033 \\
(1.2)\end{array}$ \\
\hline $\begin{array}{l}\text { Share high educated, } \\
\text { rich }\end{array}$ & & & $\begin{array}{l}0.019 \\
(1.1)\end{array}$ \\
\hline $\begin{array}{l}\text { Share low educated, } \\
\text { poor }\end{array}$ & & & $\begin{array}{c}0.040 \\
(0.9) \\
\end{array}$ \\
\hline $\begin{array}{l}\text { Share high educated, } \\
\text { poor }\end{array}$ & & & $\begin{array}{l}0.092 * * \\
(2.5)\end{array}$ \\
\hline $\log ($ GNIC $)$ & $\begin{array}{c}-2.9 * * \\
(3.1)\end{array}$ & $\begin{array}{c}-4.0 * * \\
(3.5)\end{array}$ & $\begin{array}{c}-4.4 * * \\
(4.8)\end{array}$ \\
\hline GCI & $\begin{array}{c}.81 \\
(1.0)\end{array}$ & $\begin{array}{c}.60 \\
(0.8)\end{array}$ & $\begin{array}{l}1.4^{* *} \\
(2.1)\end{array}$ \\
\hline $\mathrm{R}^{2}$ & 0.608 & 0.666 & 0.731 \\
\hline adjusted $\mathrm{R}^{2}$ & 0.535 & 0.589 & 0.641 \\
\hline Log-likelihood & -52.2 & -49.6 & -46.0 \\
\hline
\end{tabular}

Brazil, Mexico and New Zealand are missing. Further notes are similar to those reported in Table 2. 
Table 5: Explaining growth from TEA and gender composition of entrepreneurship $(\mathbf{N}=36)$

\begin{tabular}{|l|c|c|c|}
\hline & Model 1 & Model 2 & Model 3 \\
\hline Constant & $29.1^{* *}$ & $38.7^{* *}$ & $36.4^{* *}$ \\
& $(3.7)$ & $(3.6)$ & $(3.5)$ \\
\hline TEA & 0.025 & & $0.15^{* *}$ \\
& $(0.4)$ & & $(2.2)$ \\
\hline TEA rich & & $0.12^{* *}$ & -0.11 \\
& & $(2.0)$ & $(1.1)$ \\
\hline TEA poor & & -0.071 & \\
& -0.039 & $-0.8)$ & -0.026 \\
\hline Share female & $(1.2)$ & $(0.8)$ & $(1.3)$ \\
\hline Share female, rich & & & -0.012 \\
& & & $(0.3)$ \\
\hline Share female, poor & & & $-4.1^{* *}$ \\
& & $-4.2^{* *}$ & $(3.5)$ \\
\hline log (GNIC) & $(3.3)$ & $(3.4)$ & $1.5^{*}$ \\
& 1.4 & 1.2 & $(1.8)$ \\
\hline GCI & $(1.6)$ & $(1.3)$ & 0.603 \\
\hline $\mathrm{R}^{2}$ & 0.532 & 0.590 & 0.520 \\
\hline adjusted $\mathrm{R}^{2}$ & 0.472 & 0.522 & -55.9 \\
\hline Log-likelihood & -58.8 & -56.4 & \\
\hline
\end{tabular}

Notes are similar to those reported in Table 2.

\section{Footnotes}

\footnotetext{
${ }^{1}$ This reasoning is based on the population ecologist view that each new organization represents a unique formula (Hannan and Freeman, 1989).

${ }^{2}$ Also see Cohen and Klepper (1992).

${ }^{33}$ The start-up rate of individuals aged 50 years and older has increased from 8 percent in 1994 to 15 percent in 2003. For higher educated individuals (with a university degree or higher vocational training) the start-up rate increased from 29 percent in 1994 to 47 percent in 2003 . Although the female start-up rate only shows a small increase from 27 percent in 1994 to 29 percent in 2003, female entrepreneurship rates have increased worldwide in the last decades. For more details, see Bruins (2004).

${ }^{4}$ This information is retrieved from wikipedia.org (visited November $28^{\text {th }} 2006$ ).

${ }^{5}$ The idea behind the relationship between these demographic characteristics and performance is that it is valuable for the business to have a workforce that resembles the population (in terms of race and gender composition) in order to be able to serve the diverse market demand.

${ }^{6}$ Florida (2002, p. 69) argues that at the core of this so-called creative class of people there are scientists and engineers, university professors, poets and novelists, artists, actors, designers and architects, writers and opinion makers.

${ }^{7}$ Although other studies find evidence for a non-linear relationship (Evans and Leighton, 1989; Reynolds, 1997) or even a negative one (Grilo and Thurik, 2005; Uhlaner and Thurik, 2007).

${ }^{8}$ Nevertheless, Davidsson and Honig (2003) find that formal education does not predict success of new ventures in terms of first sales and profits.

${ }^{9}$ In this respect Cressy (1996) argues that human capital and not finance is the main constraint on entrepreneurial income.

${ }^{10}$ Burke et al. (2000) argue that an increase in education can reduce self-employment, but may improve the performance of those who choose self-employment.

${ }^{11}$ For the share of entrepreneurs with low education the percentages for the GEM education variables 'none' and 'some secondary education' are summated. Furthermore, for the middle education category the GEM variable 'secondary education' is used, while the high education category is a summation of the GEM variables labeled 'post secondary education' and 'graduate experience'.
} 
${ }^{12}$ The 36 countries in our sample are: Argentina $^{\mathrm{P}}$, Australia, Belgium, Brazil ${ }^{\mathrm{P}}$, Canada, Chile ${ }^{\mathrm{P}}, \mathrm{China}^{\mathrm{P}}$, Taiwan, Denmark, Finland, France, Germany, Hong Kong, Hungary, Iceland, India ${ }^{\mathrm{P}}$, Ireland, Israel, Italy, Japan, Korea, Mexico ${ }^{\mathrm{P}}$, Netherlands, New Zealand, Norway, Poland ${ }^{\mathrm{P}}$, Russia ${ }^{\mathrm{P}}$, Singapore, Slovenia, South Africa ${ }^{\mathrm{P}}$, Spain, Sweden, Switzerland, Thailand $^{\mathrm{P}}$, United Kingdom and United States. Mark ${ }^{\mathrm{P}}$ indicates a poor country. The richest of the eleven relatively poor countries is Hungary with a 2001 per capita income of 12,570 US \$. The poorest of the twenty-five relatively rich countries is Taiwan with a 2001 per capita income of 16,761 US \$. Hence, there is a clear gap between the two groups of countries in terms of GNIC.

${ }^{13}$ The minimum of 0 percent for low education corresponds to Russia. This does not imply that education levels among Russian entrepreneurs are extremely high. Instead the group of middle-educated entrepreneurs (secondary education) is relatively large (54\%), according to our data. Also note that the number of observations is 33 here. Data on education were missing for Brazil and New Zealand while we judged the data for Mexico to be implausible (70\% of entrepreneurs having high education according to the data base). Therefore we removed Mexico as well for the education diversity analysis.

${ }^{14}$ The likelihood ratio test confirms that the two models are significantly different. The test statistic equals 5.2 (two times the difference between log-likelihood values) while the critical value for one degree of freedom at $5 \%$ level equals 3.84 .

${ }^{15}$ A likelihood ratio test comparing models 2 and 3 reveals that the new variables in model 3 add significantly to the model fit. The LR test statistic equals 6.2 while the critical value for two degree of freedom at 5\% level equals 5.99.

${ }^{16}$ From a Schumpeterian perspective it may be argued that in modern economies particularly younger entrepreneurs contribute to the process of creative destruction.

${ }^{17}$ Opportunity-based entrepreneurship refers to people who start their own business by taking advantage of an entrepreneurial opportunity. Necessity-based entrepreneurship involves people who start a business because other employment options are either absent or unsatisfactory (Minniti et al., 2006).

${ }^{18}$ Reynolds et al. (2002) find that about 20 percent of the entrepreneurs expect to provide no jobs, of which about 53 percent were necessity entrepreneurs. Also, more than 25 percent of the entrepreneurs expected to provide more than 20 jobs in five years, of whom 70 percent were motivated by opportunity. In addition, 9 percent of all opportunity entrepreneurs expect to create a new market, compared to 5 percent of necessity entrepreneurs.

${ }^{19}$ These regression results are available upon request. 


\section{Publications in the ERIM Report Series Research* in Management}

\section{ERIM Research Program: "Organizing for Performance"}

2007

Leadership Behaviour and Upward Feedback: Findings From a Longitudinal Intervention

Dirk van Dierendonck, Clare Haynes, Carol Borrill and Chris Stride

ERS-2007-003-ORG

http://hdl.handle.net/1765/8579

The Clean Development Mechanism: Institutionalizing New Power Relations

Bettina B.F. Wittneben

ERS-2007-004-ORG

http://hdl.handle.net/1765/8582

How Today's Consumers Perceive Tomorrow's Smart Products

Serge A. Rijsdijk and Erik Jan Hultink

ERS-2007-005-ORG

http://hdl.handle.net/1765/8984

Product Intelligence: Its Conceptualization, Measurement and Impact on Consumer Satisfaction

Serge A. Rijsdijk, Erik Jan Hultink and Adamantios Diamantopoulos

ERS-2007-006-ORG

http://hdl.handle.net/1765/8580

Testing the Strength of the Iron Cage: A Meta-Analysis of Neo-Institutional Theory

Pursey P.M.A.R. Heugens and Michel Lander

ERS-2007-007-ORG

http://hdl.handle.net/1765/8581

Export Orientation among New Ventures and Economic Growth

S. Jolanda A. Hessels and André van Stel

ERS-2007-008-ORG

http://hdl.handle.net/1765/8583

Allocation and Productivity of Time in New Ventures of Female and Male Entrepreneurs

Ingrid Verheul, Martin Carree and Roy Thurik

ERS-2007-009-ORG

http://hdl.handle.net/1765/8989

Cooperating if one's Goals are Collective-Based: Social Identification Effects in Social Dilemmas as a Function of Goal-Transformation David De Cremer, Daan van Knippenberg, Eric van Dijk and Esther van Leeuwen

ERS-2007-010-ORG

http://hdl.handle.net/1765/9041

Unfit to Learn? How Long View Organizations Adapt to Environmental Jolts

Pursey P. M. A. R. Heugens and Stelios C. Zyglidopoulos

ERS-2007-014-ORG

http://hdl.handle.net/1765/9404

Going, Going, Gone. Innovation and Exit in Manufacturing Firms

Elena Cefis and Orietta Marsili

ERS-2007-015-ORG

http://hdl.handle.net/1765/9732 
High in the Hierarchy: How Vertical Location and Judgments of Leaders' Power are Interrelated

Steffen R. Giessner and Thomas W. Schubert

ERS-2007-021-ORG

http://hdl.handle.net/1765/9727

Contracts to Communities: a Processual Model of Organizational Virtue

Pursey P.M.A.R. Heugens, Muel Kaptein and J. van Oosterhout

ERS-2007-023-ORG

http://hdl.handle.net/1765/9728

Why Are Some Entrepreneurs More Innovative Than Others?

Philipp Koellinger

ERS-2007-024-ORG

http://hdl.handle.net/1765/9730

Stimulating Strategically Aligned Behaviour Among Employees

Cees B. M. van Riel, Guido Berens and Majorie Dijkstra

ERS-2007-029-ORG

http://hdl.handle.net/1765/10067

The Effectiveness of Business Codes: A Critical Examination of Existing Studies and the Development of an Integrated Research Model

Muel Kaptein and Mark Schwartz

ERS-2007-030-ORG

http://hdl.handle.net/1765/10150

Knowledge Spillovers and Entrepreneurs' Export Orientation

Dirk De Clercq, Jolanda Hessels and André van Stel

ERS-2007-038-ORG

http://hdl.handle.net/1765/10178

Silicon Valley in the Polder? Entrepreneurial Dynamics, Virtuous Clusters and Vicious Firms in the Netherlands and Flanders Willem Hulsink, Harry Bouwman and Tom Elfring

ERS-2007-048-ORG

http://hdl.handle.net/1765/10459

An Incomplete Contracting Model of Governance Structure Variety in Franchising

George Hendrikse and Tao Jiang

ERS-2007-049-ORG

http://hdl.handle.net/1765/10462

On the Evolution of Product Portfolio Coherence of Cooperatives versus Corporations: An Agent-Based Analysis of the Single Origin Constraint

George Hendrikse and Ruud Smit

ERS-2007-055-ORG

http://hdl.handle.net/1765/10505

Greenfield or Acquisition Entry: A Review of the Empirical Foreign Establishment Mode Literature

Arjen H.L. Slangen and Jean-François Hennart

ERS-2007-059-ORG

http://hdl.handle.net/1765/10539

Do Multinationals Really Prefer to Enter Culturally-Distant Countries Through Greenfields Rather than Through Acquisitions?

The Role of Parent Experience and Subsidiary Autonomy

Arjen H.L. Slangen and Jean-François Hennart

ERS-2007-060-ORG

http://hdl.handle.net/1765/10538 
The Financial Centres of Shanghai and Hong Kong: Competition or Complementarity?

Bas Karreman and Bert van der Knaap

ERS-2007-062-ORG

http://hdl.handle.net/1765/10516

Peer Influence in Network Markets: An Empirical Investigation

Jörn H. Block and Philipp Köllinger

ERS-2007-063-ORG

http://hdl.handle.net/1765/10540

Clustering in ICT: From Route 128 to Silicon Valley, from DEC to Google, from Hardware to Content Wim Hulsink, Dick Manuel and Harry Bouwman

ERS-2007-064-ORG

http://hdl.handle.net/1765/10617

Leader Affective Displays and Attributions of Charisma: The Role of Arousal

Frederic Damen, Daan van Knippenberg and Barbara van Knippenberg

ERS-2007-067-ORG

http://hdl.handle.net/1765/10621

Unity through Diversity: Value-in-Diversity Beliefs, Work Group Diversity, and Group Identification

Daan van Knippenberg, S. Alexander Haslam and Michael J. Platow

ERS-2007-068-ORG

http://hdl.handle.net/1765/10620

Entrepreneurial Diversity and Economic Growth

Ingrid Verheul and André van Stel

ERS-2007-070-ORG

http://hdl.handle.net/1765/10619

Commitment or Control? Human Resource Management Practices in Female and Male-Led Businesses Ingrid Verheul

ERS-2007-071-ORG

http://hdl.handle.net/1765/10618

* A complete overview of the ERIM Report Series Research in Management: https://ep.eur.nl/handle/1765/1

ERIM Research Programs:

LIS Business Processes, Logistics and Information Systems

ORG Organizing for Performance

MKT Marketing

F\&A Finance and Accounting

STR Strategy and Entrepreneurship 